\title{
Macroinvertebrates under stochastic hydrological disturbance in Cerrado streams of Central Brazil
}

\author{
Victor S. Saito \& Gustavo R. Mazão
}

Programa de Pós-Graduação em Ecologia e Recursos Naturais, Centro de Ciências Biológicas e da Saúde, Universidade Federal de São Carlos. Rod. Washington Luís, Km 235, 13565-905, São Carlos, SP, Brazil. (victor.saito@gmail.com)

\begin{abstract}
In the Cerrado vegetation, where the seasonal is well defined, rainfall has an important role in controlling the flow of streams and consequently on the structure of macroinvertebrates community. Despite the effects of rainfall associated with seasonality are well studied, little is known about the effects of stochastic rains on the community. In the present study we evaluated the structure and faunal composition of four first-order streams in Central Brazil during the dry season in two years, with and without stochastic rains. Community sampling was done by colonization of boards of high density polyethylene (HDPE), removed after one month submerged in streams. Analysis of Variance (ANOVA) performed indicated no difference in rarefied richness between the two periods, different from numeric density of organisms that was higher in the period without disturbance; moreover, the Detrended Correspondence Analysis (DCA) revealed differences in faunal composition between the two periods. Our results indicate that stochastic rainfall is an important factor in structuring the macroinvertebrates community in studied region.
\end{abstract}

KEYWORDS. Rainfall, faunal structure, rarefied richness, numeric density, benthic fauna.

RESUMO. Macroinvertebrados sob perturbações hidrológicas estocásticas em riachos de Cerrado do Brasil Central. No Cerrado, onde o regime pluviométrico é bem definido, as chuvas tem um importante papel no controle da vazão dos riachos e, por consequência, sobre a estruturação da fauna de macroinvertebrados. Apesar dos efeitos das chuvas associados à sazonalidade serem bem estudados, pouco se sabe a respeito dos efeitos de chuvas estocásticas sobre a comunidade. No presente estudo nós avaliamos a estrutura e a composição faunística de quatro riachos de primeira ordem no Brasil Central na estação seca em dois anos, com e sem chuvas estocásticas. A amostragem da comunidade foi feita através da colonização de placas de polietileno de alta densidade (PEAD), removidas após um mês submersas nos riachos. A Análise de Variância (ANOVA) realizada não indicou diferença da riqueza rarefeita entre os dois períodos coletados, diferente da densidade numérica de organismos que se mostrou maior no período em que não houve perturbação; além disso, a Análise de Correspondência Destendenciada (DCA) revelou diferenças na composição faunística entre os dois períodos. Nossos resultados indicam que as chuvas estocásticas são um importante fator na estruturação da fauna de macroinvertebrados na região estudada.

PALAVRAS-CHAVE. Chuva, estrutura faunística, riqueza rarefeita, densidade numérica, fauna bentônica.

One of several factors structuring benthic fauna is the physical disturbance caused by changes in flow (RESH et al., 1988). Although some studies indicates negative impacts of these disturbances on community (СовB et al., 1992; FLeCKER \& FeIFAREK, 1994; Bispo \& OliVeIRA, 2007), others had indicated increase in species richness of these organisms (TownSEND \& SCARSBROOK, 1997; MCCABE \& Gotelli, 2000). Considering that resistance and resilience of the community to flow oscillations depend particularly on the taxa involved (DeAth \& Winterbourn, 1995), the assessment of faunal composition provides more accurate results about community response.

In lotic environments, the rainfall is the main factor determining fluctuations in flow which in turn affect the structure of benthic community (FLECKER \& Feifarek, 1994; Bispo \& Oliveira, 2007). In regions with a well-defined seasonal, decrease in abundance of macroinvertebrate community is registered in response to changes in flow (BISPO et al., 2001; Buss et al., 2004). Studies in Cerrado vegetation indicates a strong influence of seasonal rains on the benthic community (Bispo \& Oliveira, 1998; Bispo et al., 2001; Bispo et al., 2006; Bispo \& Oliveira, 2007). Although Bispo et al. (2006) emphasized a greater influence of seasonal precipitation on the fauna in intermediate order (3rd and 4th order) streams, is expected that the impact of the rain in first orders streams are more intense, considering that a small amount of water would be enough to a significant increase in flow.

Since most studies involving the impacts of rainfall on the benthic fauna are associated with seasonal changes (Flecker \& FeIFAREK, 1994; Buss et al., 2004; Bispo \& Oliveira, 2007) little is known about impacts of stochastic rainfall. CARVALHO \& UIEDA (2004) testing the colonization of different substrates during the dry season were surprised by an event of heavy rainfall and found a reduction in the abundance of macroinvertebrates. Buss et al. (2004) comparing the benthic fauna in streams of Serra do Mar in the dry and rainy seasons, suggested that the impacts of rainfall of similar intensity generate different responses, being more severe in the dry season.

Accordingly, the aim of this study was to evaluate the effects of stochastic hydrological disturbances caused by unexpected rainfall in dry season on the benthic community of Cerrado streams in CentralBrazil, answering the following questions: in case of disturbance, there is reduction in richness and density of macroinvertebrates? Such events modify the composition of community?

\section{MATERIAL AND METHODS}

Study area. This study was conducted at Mimoso de Goiás, located in the northeast of the state 


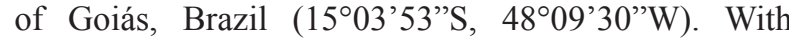
a terrain composed of mountains and valleys which present Cerrado stricto sensu vegetation, this region is characterized by a predominance of pastures used in animal agriculture. Another characteristic of this region is a well-defined pluviometric regime, this characteristic divides the year into two seasons, a dry season from May to September when rain events are infrequent, and a rainy season from October to April in which rainy events are very common.

The region is part of Tocantins-Araguaia basin, which main water body is the Maranhão River. The tributaries of this river, in general, are originated in valleys with well-preserved riparian vegetation and similar structural characteristics. Some characteristics of these streams are patches of rock with pebbles in riffles and patches of pools with deposits of gravel and organic matter (leaves and sticks).

Methods. We analyzed the fauna of four firstorder streams in two dry seasons in consecutive years. The first sampling period was in September 2009, when unexpected rains occurred and we considered the disturbed period. In this month the precipitation was of $96.5 \mathrm{~mm}$ divided mainly in three stochastic rains in the days: $10(37 \mathrm{~mm}), 21(14 \mathrm{~mm})$ and $23(31.5 \mathrm{~mm})$. The second sampling period was in August 2010, when did not occurred precipitation (undisturbed period and monthly precipitation of $0 \mathrm{~mm}$ ) (Fig. 1).

At each sampling period, in the four streams we fixed eight boards of high density polyethylene, with surface of $576 \mathrm{~cm}^{2}(24 \times 24 \mathrm{~cm})$ in the first day of the month and left for 30 days for macroinvertebrates colonization.

The removal of boards was always done in the downstream to upstream direction, to avoid interference in the others boards, with the aid of a D-net $(250 \mu \mathrm{m})$. The deposited material were removed with a soft brush and fixed in alcohol solution (70\%). Macroinvertebrates were sorted under a stereomicroscope and identified to lowest possible level using identification keys of Domínguez \& Fernández (2009). The identified organisms are deposited in the collection of Laboratório de Ecologia de Insetos Aquáticos of Departamento de Hidrobiologia, Universidade Federal de São Carlos (UFSCar), state of São Paulo, Brazil.

Data analysis. For most taxa, as more individuals are collected, as greater the number of species, genera or families found, making comparison between total richness of samples with different number of individuals or replications incorrect (Gotelli \& Colwell, 2001). To make correct comparisons between richness, it should be performed rarefaction curves, which are produced by repeatedly re-sampling the pool of $\mathrm{N}$ individuals or $\mathrm{S}$ samples, at random, and plotting the average number of species represented by $\mathrm{N}$ individuals or $\mathrm{S}$ samples (Gotelli, 2008). This procedure standardizes the comparison to the sample with the smallest number of individuals or samples. In our case we used the smallest number of individuals for rarefied richness calculation.

To evaluate the differences of standardized richness (rarefied) and density of organisms of the benthic fauna between the disturbed (September, 2009) and the undisturbed period (August, 2010) we conducted an Analysis of Variance (ANOVA). To analyze modification on fauna structure and composition between the two periods we also performed a Detrended Correspondence Analysis (DCA) in which their scores (axis 1) were tested in ANOVA for statistical confirmation.

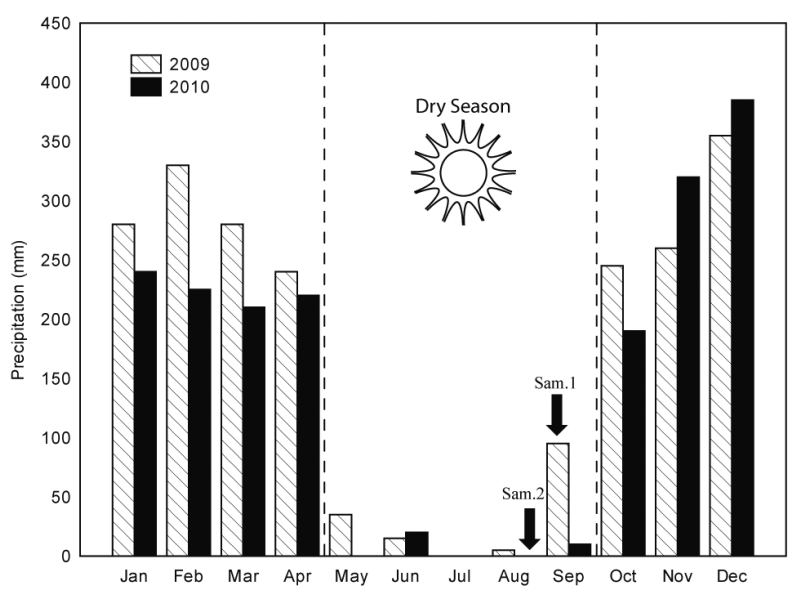

Fig. 1. Graphic of accumulated pluviometric monthly values for 2009 and 2010, indicating sampling periods in Mimoso de Goiás (state of Goiás, Brazil) (Sam. 1 and Sam. 2).

\section{RESULTS}

We collected 2,581 organisms in the two sampling periods, identified in 23 different taxa, being 17 to genus level, 3 to subfamily (Chironomidae) and 3 to family level (Tab. I). The most abundant taxonomic group was Chironominae (Diptera, Chironomidae), followed by Cloedes sp. (Ephemeroptera, Baetidae) and Tanypodinae (Chironomidae). The taxa Gyretes sp., Gyrinus sp. (Coleoptera, Gyrinidae), Helicopsyche sp. (Trichoptera, Helicopsychidae) and Simuliidae (Diptera) were found only in the disturbed period, while Hexacylloepus sp. (Coleoptera, Elmidae), Tropisternus sp. (Coleoptera, Hydrophilidae), Ceratopogonidae and Tipulidae (Diptera) were found only in the undisturbed period.

We do not found statistically difference in richness between the sampling periods $(\mathrm{df}=1, \mathrm{~F}=1.88$, $p=0.21$ ), but the average value of richness was higher in disturbed period. In contrast, density was statistically different between periods $(\mathrm{df}=1, \mathrm{~F}=5.45, \mathrm{p}=0.05)$, being higher in undisturbed period. For composition, DCA scores (axis 1) indicated differences on faunal composition between periods $(\mathrm{df}=1, \mathrm{~F}=9.57, \mathrm{p}=0.002)$. According to DCA, in disturbed period the faunal composition had a low similarity among sampling sites, opposed to undisturbed samples, when the composition was more similar (Fig. 2). 
Tab. I. Table of identified taxa and relative abundance of macroinvertebrate community in streams of Mimoso de Goiás (state of Goiás, Brazil) in periods with and without stochastic rains.

\begin{tabular}{|c|c|c|c|c|}
\hline Order & Family & Genus or subfamily & Disturbed \% & Undisturbed \% \\
\hline \multirow[t]{3}{*}{ Ephemeroptera } & Baetidae & Cloedes & 16.61 & 17.38 \\
\hline & Leptophlebiidae & Miroculis & 0.94 & 0.58 \\
\hline & Leptohyphidae & Leptohyphes & 0.12 & 0.46 \\
\hline \multirow[t]{5}{*}{ Trichoptera } & Calamoceratide & Phylloicus & 0.12 & 0.06 \\
\hline & Helicopsychidae & Helicopsyche & 1.40 & 0.00 \\
\hline & Hydroptilidae & Oxyethira & 0.12 & 0.75 \\
\hline & Leptoceridae & Oecetis & 0.35 & 0.12 \\
\hline & Polycentropodidae & Cyrnellus & 0.35 & 0.41 \\
\hline \multirow[t]{5}{*}{ Coleoptera } & Elmidae & Heterelmis & 0.12 & 0.06 \\
\hline & & Hexacylloepus & 0.00 & 0.12 \\
\hline & Gyrinidae & Gyretes & 0.12 & 0.00 \\
\hline & & Gyrinus & 0.12 & 0.00 \\
\hline & Hydrophilidae & Tropisternus & 0.00 & 0.06 \\
\hline \multirow[t]{6}{*}{ Diptera } & Chironomidae & Chironominae & 43.16 & 59.33 \\
\hline & & Orthocladiinae & 11.11 & 4.46 \\
\hline & & Tanypodinae & 22.34 & 14.83 \\
\hline & Ceratopogonidae & & 0.00 & 0.06 \\
\hline & Simuliidae & & 0.35 & 0.00 \\
\hline & Tipulidae & & 0.00 & 0.06 \\
\hline Hemiptera & Notonectidae & Notonecta & 0.82 & 0.12 \\
\hline \multirow[t]{3}{*}{ Odonata } & Calopterygidae & Hetaerina/Mnesarete & 0.47 & 0.06 \\
\hline & Coenagrionidae & Argia & 0.35 & 0.17 \\
\hline & Libellulidae & Dythemis & 1.05 & 0.93 \\
\hline
\end{tabular}

\section{DISCUSSION}

The lower density found in the disturbed period is an expected result considering other authors' findings, who also observed a lower abundance of macroinvertebrates in environments with increased disturbance, whether manipulated (MCCABE \& GotelLI, 2000) or natural (Flecker \& FeifareK, 1994; Death \& Winterbourn, 1995; Bradt et al., 1999; Buss et al., 2004; Carvalho \& Uieda, 2004; Bispo et al., 2006).

The low density of organisms in disturbed periods is explained according to BISPO et al. (2006) and FLECKER \& FeIFAREK (1994), which also studied mountainous regions and indicated the declivity as important characteristic. The increase in stream flow due to rain is higher in high declivity, consequently moving more organisms. In addition, BISPO et al. (2006) suggested that Cerrado vegetation had a low capacity to reduce the rain effects on stream flows, because this vegetation had low percolation most of the rain water reaches the streams quickly.

For standardized richness we do not found difference between disturbed and undisturbed periods. Similar results were found by BRADT et al. (1999) and Buss et al. (2004), which identified decrease in abundance, but not in richness in periods after disturbances (floods). Despite the absence of significant difference, we noted that the richness values (average) were higher in the disturbed period, similar to others authors (Townsend \& SCARSBRooK, 1997; McCABE \& Gotelli, 2000).

Currently, according to Resh et al. (1988) and
McCABe \& Gotelli (2000) the most accepted model to explain the changes in richness and diversity in aquatic environments is the dynamic equilibrium (HUSTON, 1979). In this model the highest richness can be found in low, medium or high levels of disturbance, depending on the rate of population growth.

According to the dynamic equilibrium model, the tendency to find higher richness after a disturbance can occur when the population growth rates are high enough to generate competitive exclusion, reducing species richness. In these cases, disturbances decreases density preventing competitive exclusion and enabling the establishment of different taxa.

In our study, even with the highest density in undisturbed period, we do not observed a decrease in richness. This may have occurred because the boards were colonized by only one month and this period may not have been long enough to occur competitive exclusion of species.

TOWNSEND \& SCARSBRoOK (1997) found a higher richness in disturbed period using total richness in data comparison, in contrast to MCCABE \& Gotelli (2000), as in present study, found this result using a rarefaction technique for richness estimation. As abundance is positively related to total richness (Gotelli \& Graves, 1996) and disturbance decreases abundance, less species by area are expected in disturbed environments. Based on that, rarefied richness avoids estimating a lower richness in disturbed environment, incorrectly. So studies that used total richness or species density may have discussed data disguised by influence of sample sizes (MCCABE \& GoTELLI, 2000). 


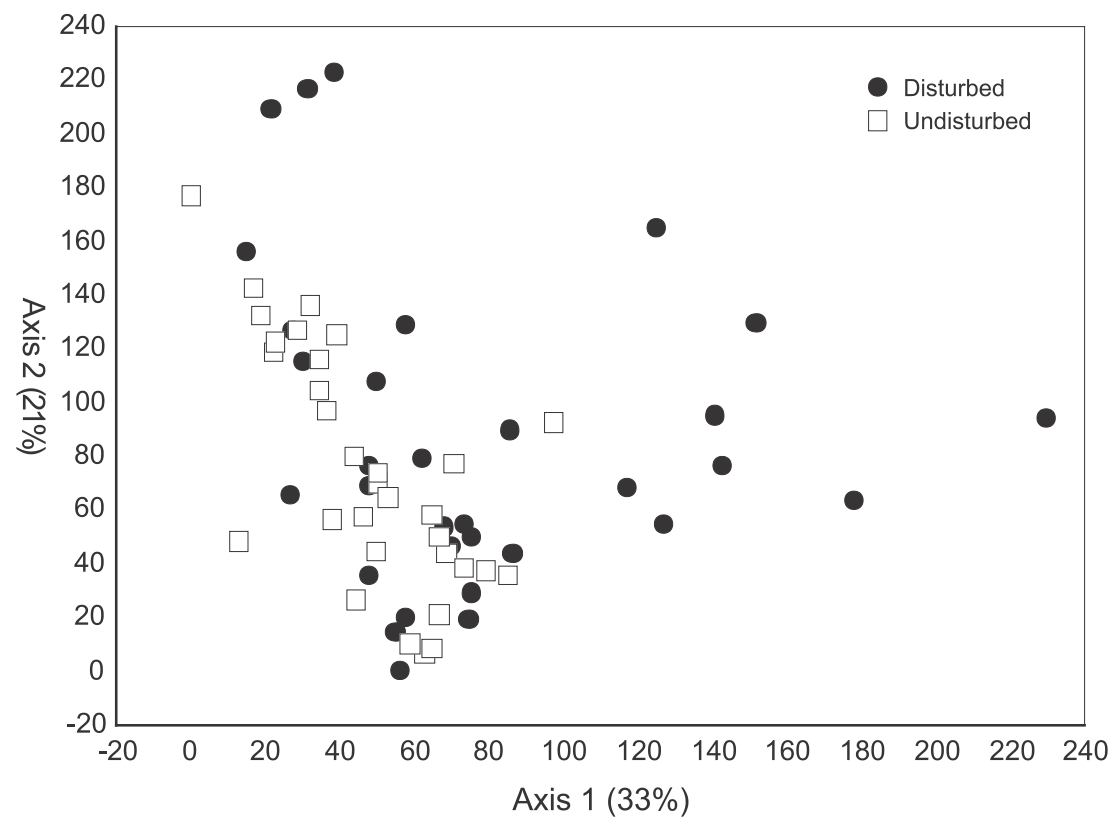

Fig. 2. Graphic of faunal composition of macroinvertebrate community of four streams in Mimoso de Goiás (state of Goiás, Brazil), obtained by Detrended Correspondence Analysis (DCA).

According to DCA, by influence of disturbance there was less similarity of fauna composition between sample sites, indicating a variation in community composition when stochastic rains occur. Our results corroborate other studies that indicate stochastic rains and substrate disturbances as important factors in aquatic community organization (RESH et al., 1988; Flecker \& Feifarek, 1994; Bispo et al., 2001; Carvalho \& UIEDA, 2004; BISPO et al., 2006). The lower similarity in composition (DCA) suggests a reorganization of aquatic insects due to alterations on microhabitats, which probably modifies the spatial distribution pattern of species (Bispo \& Oliveira, 1998; Diniz-Filho et al., 1998).

In disturbed period, with the increase in flow, the presence of Gyretes sp. and Simuliidae corroborate studies that indicate the preference and higher abundance of these two taxa to fast water environments (BENETTI et al., 1998; Benetti \& Hamada, 2003; Santos JR. et al., 2007; FigUEIRÓ et al., 2012). The opposite occurred with Gyrinus sp., because this genus was also present in this period while studies indicate the preference to lentic environments and pools in streams (BENETTI et al., 1998, SEgura et al., 2012).

During the undisturbed period, when we observed lower speed of water and more pools we found Tropisternus sp. and Ceratopogonidae, agreeing with studies associating these groups to pools with leaves and twigs (BenetTi et al. 1998; ArChangelsky et al., 2009; Grosso, 2009).

Several studies showed that Trichoptera are less resistant to changes in flow during rainy season, indicating that this taxon is a bad swimmer (consequently a bad colonizer) and not hydrodynamic, compared to others groups (e.g. Plecoptera and Ephemeroptera)
(Faessel, 1985; Bispo et al., 2001; Oliveira \& Bispo, 2001). Our results partially corroborate those studies, since each morphotype responded differently to high flow, with genera increasing in abundance (Oecetis sp., Helicopsyche sp.) and others decreasing (Oxyethira sp., Cyrnellus sp.).

The morphotype Oxyethira sp. (Trichoptera, Hydroptilidae) was more abundant in undisturbed period, similar to others studies (BRADT et al., 1999; MCCABE \& Gotelli, 2000), that registered higher abundance of Hydroptilidae and Leucotrichia sp. in undisturbed experiments, respectively. Although results of these studies suggests a possible fragility of Hydroptilidae, Oliveira \& Bispo (2001) found Dicaminus sp. and Hydroptila sp. associated to high flow environments, invalidating the generalization of this fragility to family level considering that each specie respond differently.

Our results indicates that stochastic and unexpected rains in dry season of Cerrado streams have a strong influence in structuring of macroinvertebrate community, decreasing numeric density of organisms and changing taxonomic composition. However, for taxonomic richness our results did not indicated in which model of diversity the studied community fits, requiring other methods and experimental designs to answer this question specifically. Concluding, we also suggest that other methodologies should be tested, analyzing the macroinvertebrate response immediately after a rain event and the colonization pattern of the fauna in different levels and frequency of disturbance.

Acknowledgements. The authors are grateful to Daniel Ors Laranjeiras, Joaquim Vieira Fernandes and Juliana Beatriz Souza Leite, for helping in field works and to Fapesp and Capes for scholarships granted to V.S.S. (process 2011/15077-3) and G.R.M., respectively. 


\section{REFERENCES}

Archangelsky, M.; Manzo, V.; Michat, M. C.; Torres, P. L. M. 2009. Coleoptera. In: Domínguez, E. \& Fernández, H. R. eds. Macroinvertebrados bentónicos sudamericanos: sistemática y biología. Tucumán, Fundación Miguel Lillo. v. 1, p. 411-469.

Benetti, C. J. \& Hamada, N. 2003. Fauna de coleópteros aquáticos (Insecta: Coleoptera) na Amazônia Central, Brasil. Acta Amazonica 33:701-710.

Benetti, C. J.; Fiorentin, G. L.; Regil Cueto, J. A.; Pacho Miguel, R. R. 1998. Coleopterofauna aquática na Floresta Nacional de São Francisco de Paula, RS, Brasil. Acta Biologica Leopoldensia 20(1): 91-101

Bispo, P. C. \& Oliveira, L. G. 2007. Diversity and structure of Ephemeroptera, Plecoptera and Trichoptera (Insecta) assemblages from riffles in mountain streams of Central Brazil. Revista Brasileira de Zoologia 24(2):283-293.

Bispo, P. C.; Oliveira, L. G.; Bini, L. M. \& Sousa, K. G. 2006. Ephemeroptera, Plecoptera and Trichoptera from riffles in mountain streams of Central Brazil: environmental factors influencing the distribution and abundance of immatures. Brazilian Journal of Biology 66(2B):611-622.

Bispo, P. C.; Oliveira, L. G.; Crisci, V. L. \& Silva, M. M. 2001. A pluviosidade como fator de alteração da entomofauna bentônica (Ephemeroptera, Plecoptera e Trichoptera) em córregos do Planalto Central do Brasil. Acta Limnologica Brasiliensia 13:1-9.

Bispo, P. C. \& Oliveira, L. G. 1998. Distribuição espacial de insetos aquáticos (Ephemeroptera, Plecoptera, Trichoptera) em córregos de Cerrado do parque ecológico de Goiânia, Estado de Goiás. In: Nessimian, J. L. \& Carvalho, A. L. eds. Ecologia de insetos aquáticos. Rio de Janeiro, PPGE - UFRJ (Série Oecologia Brasiliensis). v. 5, p. 175-189.

Bradt, P.; Urban, M.; Goodman, N.; Bissell, S. \& Spiegel, I. 1999. Stability and resilience in benthic macroinvertebrate assemblages. Hydrobiologia 403:123-133.

Buss, D. F.; Baptista, D. F.; Nessimian, J. L. \& Egler, M. 2004. Substrate specificity, environmental degradation and disturbance structuring macroinvertebrate assemblages in neotropical streams. Hydrobiologia 518:179-188.

Carvalho, E. M. \& Uieda, V. S. 2004. Colonization by benthic macroinvertebrates in artificial and natural substrates in a mountain stream from Itatinga, São Paulo, Brazil. Revista Brasileira de Zoologia 21:287-293.

CobB, D. G.; Galloway, T. D. \& Flannagan, J. F. 1992. Effects of Discharge and Substrate Stability on Density and Species Composition of Stream Insects. Canadian Journal of Fisheries and Aquatic Sciences 49(9):1788-1795.

Death, R. G. \& Winterbourn, M. J. 1995. Diversity patterns in stream benthic invertebrate communities: the influence of habitat stability. Ecology 76:1446-1460.

Diniz-Filho, J. A. F.; Oliveira, L. G. \& Silva, M. M. 1998. Explaining the beta diversity of aquatic insects in "Cerrado" streams from
Central Brazil using Multiple Mantel Test. Revista Brasileira de Biologia 58(2):223-231.

DomíngueZ, E. \& FernÁndeZ, H. R. 2009. Macroinvertebrados bentónicos sudamericanos: sistemática y biología. Tucumán, Fundación Miguel Lillo. 654p.

FAessel, B. 1985. Les Trichoptéres. Donnés biologiques, éthologiques et écologiques. Clés de determination larvaire des principaux genres de France. Bulletin Francais de la Peche et de la Pisciculture 299:1-41.

Figueiró, R.; Gil-Azevedo, L. H.; Maia-Herzog, M.; Monteiro, R. F. 2012. Diversity and microdistribution of black fly (Diptera: Simuliidae) assemblages in the tropical savanna streams of the Brazilian cerrado. Memórias do Instituto Oswaldo Cruz 107:362-369

Flecker, A. S. \& Feifarek, B. 1994. Disturbance and the temporal variability of invertebrate assemblage in two Andean streams. Freshwater Biology 31:131-132.

Gotelli, N. J. 2008. A Primer of Ecology, Fourth Edition. Sunderland, Sinauer Associates. 291p.

Gotelli, N. J. \& Colwell, R. K. 2001. Quantifying biodiversity: procedures and pitfalls in the measurement and comparison of species richness. Ecology Letters 4:379-391.

Gotelli, N. J. \& Graves, G. R. 1996. Null Models in Ecology Washington, Smithsonian Institution Press. 388p.

Grosso, M. L. 2009. Diptera: generalidades. In: Domínguez, E. \& FernÁndez, H. R. eds. Macroinvertebrados bentónicos sudamericanos: sistemática y biología. Tucumán, Fundación Miguel Lillo. v. 1, p. 341-365.

Huston, M. 1979. A general hypothesis of species diversity. The American Naturalist 113(1):81-101.

McCABe, D. C. \& Gotelli, N. J. 2000. Effects of disturbance frequency, intensity, and area on stream macroinvertebrate communities. Oecologia 124:270-279.

Oliveira, L. G. \& Bispo, P. C. 2001. Ecologia de comunidades das larvas de Trichoptera Kirby (Insecta) em dois córregos de primeira ordem da Serra dos Pireneus, Pirenópolis, Goiás, Brasil. Revista Brasileira de Zoologia 18(4):1245-1252.

Resh, V. H.; Brown, A. V.; Covich, A. P.; Gurtz, M. E.; Li, H. W.; Minshall, W.; Reice, S. R.; Sheldon, A. L.; Wallace, B. \& Wissmar, R. C. 1988. The role of disturbance in stream ecology. Journal of North American Benthological Society 7(4):433 455.

Santos Jr, J. E.; Strieder, M. N.; Fiorentin, G. L.; Neiss, U. G. 2007. Velocidade da água e a distribuição de larvas e pupas de Chirostilbia pertinax (Kollar) (Diptera, Simuliidae) e macroinvertebrados associados. Revista Brasileira de Entomologia 51:62-66.

Segura, M. O.; Fonseca-Gessner, A. A.; Spies, M. R. \& Siegloch, A. E. 2012 .Water beetles in mountainous regions in southeastern Brazil. Brazilian Journal of Biology 72(2):311-321.

Townsend, C. R. \& SCARsBrook, M. R. 1997. The intermediate disturbance hypothesis, refugia, and biodiversity in streams. Limnology and Oceanography 42(5):938-949. 